\title{
Pelatihan Technology Use - Social Media Branding for SMEs Pemilik UKM Binaan Universitas Bina Nusantara Jakarta
}

\author{
Siti Dewi Sri Ratna Sari ${ }^{*}$ \& Donant Alananto Iskandar ${ }^{2}$ \\ ${ }^{1}$ Komunikasi, Fakultas Ekonomi dan Komunikasi, Universitas Bina Nusantara Jakarta \\ 2Manajemen, Fakultas Bisnis dan Ilmu Komunikasi, Institut Teknologi dan Bisnis Kalbis \\ Jakarta
}

\begin{abstract}
The COVID-19 pandemic has drastically reduced the number of face-to-face buying and selling transactions, thus opening up opportunities for online buying and selling transactions, especially through social media. However, the owners of SMEs (Small and Medium Enterprises) do not understand how to brand their products through social media. This training activity aims to provide knowledge for SME owners assisted by Bina Nusantara University Jakarta so that they can understand social media branding to better promote their products and increase their competitiveness in the era of globalization. The method used in this activity is in the form of online training through the Zoom application with a duration of two hours which is carried out every Friday during June 2021. The training activities carried out for the participants are material explanations and case studies, followed by a question and answer session, discussion and practice. Activity participants can take part in the training well and enthusiastically, and begin to understand how to brand their products through social media.
\end{abstract}

Keywords

Social media branding,

UKM

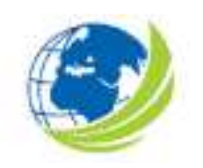

BERDAYA : Jurnal Pendidikan dan Pengabdian

Kepada Masyarakat Vol 3, No.2, Agustus 2021,

pp. $75-84$

eISSN 2721-6381

\section{Article History}

Received 09 Aug 2021 / Accepted 25 Aug 2021 / First Published: 31 Aug 2021

To cite this article

Ratna Sari, S. D. S., \& Iskandar, D. (2021). Pelatihan Technology Use - Social Media Branding for SMEs Pemilik UKM Binaan Universitas Bina Nusantara Jakarta. BERDAYA: Jurnal Pendidikan Dan Pengabdian Kepada Masyarakat, 3(2), 75 - 84

DOI: $10.36407 /$ berdaya.v3i2.426

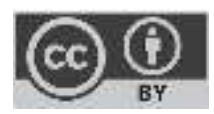

(C) The Author(s)2021

. This open access article is distributed under a Creative Commons Attribution (CC-BY) 4.0 license 


\begin{abstract}
ABSTRAK
Pandemi COVID-19 telah mengurangi secara drastis jumlah transaksi jual beli secara tatap muka, sehingga membuka peluang bagi transaksi jual beli secara daring, terutama melalui media sosial. Namun para pemilik UKM (Usaha Kecil dan Menengah) belum memahami bagaimana melakukan branding produk mereka melalui media sosial. Kegiatan pelatihan ini bertujuan untuk pembekalan pengetahuan bagi para pemilik UKM binaan Universitas Bina Nusantara Jakarta agar mereka dapat memahami social media branding untuk mempromosikan produk-produk mereka dengan lebih baik dan dapat meningkatkan daya saing mereka di era globalisasi. Metode yang digunakan dalam kegiatan ini adalah dalam bentuk pelatihan daring melalui aplikasi Zoom dengan durasi dua jam yang dilakukan pada setiap hari Jum'at selama bulan Juni 2021. Kegiatan pelatihan yang dilakukan bagi para peserta adalah penjelasan materi dan studi kasus, dilanjutkan dengan sesi tanya jawab, diskusi serta praktek. Peserta kegiatan dapat mengikuti pelatihan dengan baik dan antusias, serta mulai memahami untuk melakukan branding produk mereka melalui media sosial.
\end{abstract}

Kata Kunci : Social media branding, UKM
Profil Penullis

Siti Dewi Sri Ratna Sari

Komunikasi, Fakultas Ekonomi

dan Komunikasi, Universitas Bina

Nusantara Jakarta

Jl. K.H. Syahdan No. 9, Jakarta

Barat 11480

Donant Alananto Iskandar

Manajemen, Fakultas Bisnis dan

Ilmu Komunikasi, Institut

Teknologi dan Bisnis Kalbis

Jakarta

\section{PENDAHULUAN}

Pandemi COVID-19 yang berlangsung sejak akhir Maret 2020 hingga saat ini telah meruntuhkan perekonomian hampir seluruh lapisan masyarakat Indonesia. Para pemilik UKM pun tak luput terimbas dampaknya. Badan Pusat Statistik (BPS, 2020) mencatat 25,53 persen usaha mengalami penurunan lebih dari 75 persen, dengan 33,70 persen di antaranya adalah usaha penyediaan akomodasi dan penyedian makan minum. Namun pandemi COVID-19 ini juga membuka peluang yang besar bagi transaksi jual beli secara daring karena transaksi konvensional secara tatap muka dibatasi demi pencegahan penyebaran virus. Pembatasan ini tertuang dalam Peraturan Pemerintah No. 21/2020 yang ditandatangani oleh Presiden Joko Widodo pada tanggal 31 Maret 2020, yang mengatur tentang Pembatasan Sosial Berskala Besar atau sering disebut sebagai PSBB (Setkab RI, 2020). Pembatasan ini terus berlanjut ke tahun 2021 dengan penamaan yang berbeda.

Dewasa ini, berbelanja melalui e-commerce sebenarnya sudah menjadi bagian dari gaya hidup masyarakat Indonesia. Para pelaku e-commerce ini bertransaksi melalui berbagai platform, seperti situs web (website), media sosial ataupun market place (Sari \& Haryanti, 2019). Pembuatan situs web memerlukan biaya dan penanganan khusus sehingga kurang diminati oleh para pemilik UKM. Sementara itu, jika para pemilik UKM menjual produk mereka melalui market place yang menjamur seperti Tokopedia, Shopee, Bukalapak misalnya, dikenakan potongan yang cukup tinggi sebagai biaya menitipkan penjualan produk. Dengan demikian, media sosial menjadi platform yang paling diminati oleh para pemilik UKM karena proses pembuatan akun yang cenderung mudah dan hampir tanpa biaya. Hasil survei dari 
Badan Pusat Statistik (BPS, 2020) menguatkan hal tersebut dengan 65,14 persen usaha UKM memilih berjualan secara daring melalui media sosial seperti Facebook, Instagram, Twitter, dan aplikasi lainnya. Hanya 25,72 persen usaha UKM yang memiliki akun penjualan di market place dan 4,96 persen yang mempunyai situs web.

Penjualan produk melalui media sosial yang dianggap mudah dan tanpa biaya ternyata tidak sesederhana yang dibayangkan oleh para pemilik UKM tersebut. Keterbatasan mereka dalam mencari pengikut akun (follower) dan menjalin interaksi secara intens dengan mereka, membuat konten yang menarik perhatian, serta mengukur keberhasilan promosi melalui media sosial mereka menjadi kendala yang menghambat daya saing mereka dengan merek (brand) yang lebih kuat tertanam di benak konsumen. Pengetahuan dan pemahaman dalam melakukan branding produk-produk UKM melalui media sosial ini menjadi hal yang perlu mendapat perhatian agar para pemilik UKM dapat bersaing dengan lebih baik di era globalisasi.

Menurut Holt (2016), membangun merek di era Facebook dan YouTube sudah menjadi sebuah tantangan yang menyusahkan. Satu dekade lalu, berbagai perusahaan berusaha memasukkan merek ke dunia digital dengan membuat konten yang viral, meme, menggunakan buzzer, namun kurang membuahkan hasil. Rowles (2018) menyatakan bahwa digital branding adalah kepribadian organisasi, layanan, atau produk yang diciptakan oleh semua pengalaman yang dimiliki individu terhadap merek tersebut, tidak hanya mencakup hal-hal seperti identitas visual, tetapi sekarang juga mencakup interaksi di media sosial dan ulasan daring.

Berdasarkan kendala yang dihadapi para pemilik UKM di atas, mengetahui dan memahami social media branding secara keseluruhan sangat diperlukan oleh mereka agar merek produk mereka mampu bersaing dengan merek-merek yang lebih mapan. Universitas Bina Nusantara Jakarta melalui Departemen Komunikasi dan Community Development Center Teach For Indonesia dengan program Pengabdian kepada Masyarakatnya berusaha membantu para pemilik UKM tersebut. Kerjasama ini menghasilkan sebuah seri pelatihan "Social Media Branding for SMEs" yang dapat langsung diaplikasikan oleh para peserta. Pelatihan ini merupakan seri khusus yang disebut dengan "Technology Use" (Penggunaan Teknologi), juga menyertakan para mahasiswa yang akan membantu para peserta pelatihan dalam mengaplikasikan materi yang diajarkan.

\section{Sasaran Kegiatan}

Kegiatan pelatihan Technology Use - Social Media Branding for SMEs ini ditujukan bagi para pemilik UKM binaan Universitas Bina Nusantara Jakarta. Mereka bergabung melalui Community Development Center di Universitas Bina Nusantara. Sebagian besar dari mereka rutin mendapatkan informasi mengenai berbagai pelatihan yang diadakan oleh Community Development Center ini melalui program Pengabdian kepada Masyarakat. Namun pelatihan kali ini diorganisir khusus oleh Community Devlopment Center Teach For Indonesia Universitas Bina Nusantara dengan melibatkan para mahasiswa jurusan Komunikasi yang mendampingi para pemilik UKM tersebut dalam melakukan praktek penggunaan teknologi.

\section{Masalah yang ingin dipecahkan}

Membekali para pemilik UKM binaan Universitas Bina Nusantara Jakarta dengan pengetahuan tentang social media branding serta memahami bagaimana melakukan branding produk mereka melalui media sosial. 
Manfaat yang diharapkan dari pengabdian kepada masyarakat melalui pelatihan ini adalah sebagai berikut:

1. Para peserta pelatihan mengenal dan mengetahui dasar-dasar bagi Social Media Branding untuk UKM.

2. Para peserta pelatihan mengetahui strategi membuat konten yang baik di media sosial dan mempraktekkannya.

3. Para peserta pelatihan memahami taktik pemilihan media sosial yang tepat bagi produk mereka serta mampu membuat jadwal pengunggahan konten yang efektif.

4. Para peserta pelatihan juga diharapkan dapat melakukan evaluasi strategi branding melalui media sosial yang mereka telah laksanakan dan melakukan pengukuran.

\section{MATERI DAN METODE}

\section{Materi}

Materi yang diberikan pada kegiatan pengabdian masyarakat berupa pelatihan "Technology Use - Social Media Branding for SMEs", yang terbagi menjadi empat sub topik, yaitu:

1. Introduction to Social Media Branding for SMEs (Pengenalan Branding melalui Media Sosial untuk UKM)

2. Social Media Content Strategy for SMEs (Strategi Pembuatan Konten Media Sosial bagi UKM)

3. Social Media Tactic and Content Timeline for SMEs (Taktik Pemilihan Media Sosial dan Linimasa Konten bagi UKM)

4. Social Media Evaluation and Measurement (Evaluasi dan Pengukuran Media Sosial)

\section{Lokasi Kegiatan}

Pelaksanaan kegiatan pengabdian masyarakat ini dilaksanakan pada:

Hari/Tanggal : Setiap hari Jum'at di bulan Juni 2021 yaitu di tanggal 4, 11, 18 dan 25 Juni 2021.

Waktu $\quad: 14.00-16.00$ WIB (dibagi menjadi dua sesi)

Tempat : : Zoom Teach For Indonesia Universitas Bina Nusantara

\section{Peserta}

Peserta dalam kegiatan ini adalah para pemilik UKM binaan Universitas Bina Nusantara yang diorganisir oleh Community Development Center Teach For Indonesia, didampingi oleh para mahasiswa dari Departemen Komunikasi Universitas Bina Nusantara. Produk para pemilik UKM ini bervariasi mulai dari makanan, busana hingga aksesoris.

\section{Prosedur dan Metode}

Prosedur pelaksanaan kegiatan pengabdian masyarakat berupa pelatihan "Technology Use Social Media Branding for SMEs" bagi para pemilik UKM binaan Universitas Bina Nusantara ini melalui tahapan sebagai berikut:

1. Diskusi internal di Departemen Komunikasi Universitas Bina Nusantara untuk menentukan topik pelatihan yang sesuai dengan kebutuhan calon peserta, pemilihan dosen pemateri dan ruang lingkup pengajaran dosen pemateri.

2. Diskusi Koordinator Pengabdian kepada Masyarakat Departemen Komunikasi Universitas Bina Nusantara dengan Community Development Center Teach For Indonesia 
untuk mencari peserta pelatihan yang sesuai dengan topik serta para mahasiswa yang akan mendampingi para peserta.

3. Koordinator Pengabdian kepada Masyarakat Departemen Komunikasi Universitas Bina Nusantara melakukan briefing (penjelasan singkat) kepada delapan dosen calon pemateri seminggu sebelum pelaksanaan pelatihan.

4. Para dosen pemateri menyiapkan presentasi yang akan diberikan kepada para peserta.

5. Pelaksanaan kegiatan pelatihan.

6. Pelaporan kegiatan dalam bentuk artikel yang akan dipublikasikan di jurnal ilmiah.

Metode yang digunakan dalam pelatihan ini adalah metode ceramah secara daring melalui aplikasi Zoom yang diorganisir oleh Teach For Indonesia Universitas Bina Nusantara. Metode ini dipilih mengingat kegiatan pelatihan dilaksanakan pada masa pandemi COVID-19 yang tidak memungkinkan untuk melakukan pertemuan tatap muka demi mencegah penularan virus. Metode ceramah dilakukan agar dapat menjelaskan materi dan memberikan contohcontoh studi kasus dengan lebih mudah dan cepat. Metode diskusi juga digunakan untuk membahas masalah-masalah yang dihadapi oleh para pemilik UKM dalam melakukan branding produk mereka sehingga terjadi komunikasi dua arah dengan para peserta. Setelah itu, para peserta diajak mempraktekkan langsung melalui media sosial mereka. Dengan demikian, didapatkan tingkat pemahaman yang lebih baik dari para peserta tentang solusi untuk mengatasi masalah-masalah yang sering mereka hadapi dalam melakukan branding melalui media sosial.

Pemateri pada pengabdian masyarakat ini terdiri dari delapan dosen Faculty Member dari Departemen Komunikasi Universitas Bina Nusantara Jakarta yang memberikan materi masing-masing selama satu jam, terbagi menjadi dua dosen setiap minggunya.

\section{PELAKSANAAN KEGIATAN DAN EVALUASI}

\section{Pelaksanaan Kegiatan}

Kegiatan pengabdian kepada masyarakat berupa pelatihan "Technology Use - Social Media Branding for SMEs" ini dilaksanakan secara daring melalui aplikasi Zoom Teach For Indonesia Universitas Bina Nusantara pada setiap hari Jum'at di bulan Juni 2021, yaitu di tanggal 4, 11, 18 dan 25 Juni 2021 dimulai dari pukul 14.00 WIB hingga 16.00 WIB. Kegiatan pelatihan ini dimulai pada hari Jum'at, 4 Juni 2021 pukul 14.00 WIB dan dibuka dengan sesi kata sambutan dari Kepala Departemen Komunikasi Universitas Bina Nusantara, Maria Anggia Widyakusumastuti, S.Sos., M.M. Kemudian langsung dilanjutkan dengan sesi pertama pelatihan dengan topik "Introduction of Social Media Branding for SMEs" (Pengenalan Branding melalui Media Sosial untuk UKM) dengan pemberian materi yang terbagi menjadi dua sub topik, yaitu "Why SMEs Need Social Media Branding and The Success Stories in Social Media Branding" (Mengapa UKM Perlu Social Media Branding serta Kisah Sukses dengan Branding melalui Media Sosial) dengan pemateri Dina Sekar Vusparatih S.IP., M.I.Kom. di sesi pertama dan "Introduction to Instagram and Facebook Tools and Features for Social Media Branding"(Pengenalan Peralatan dan Fitur Instagram dan Facebook bagi Branding melalui Media Sosial) dengan pemateri Siti Dewi Sri Ratna Sari, S.S., M.Si. di sesi kedua. 


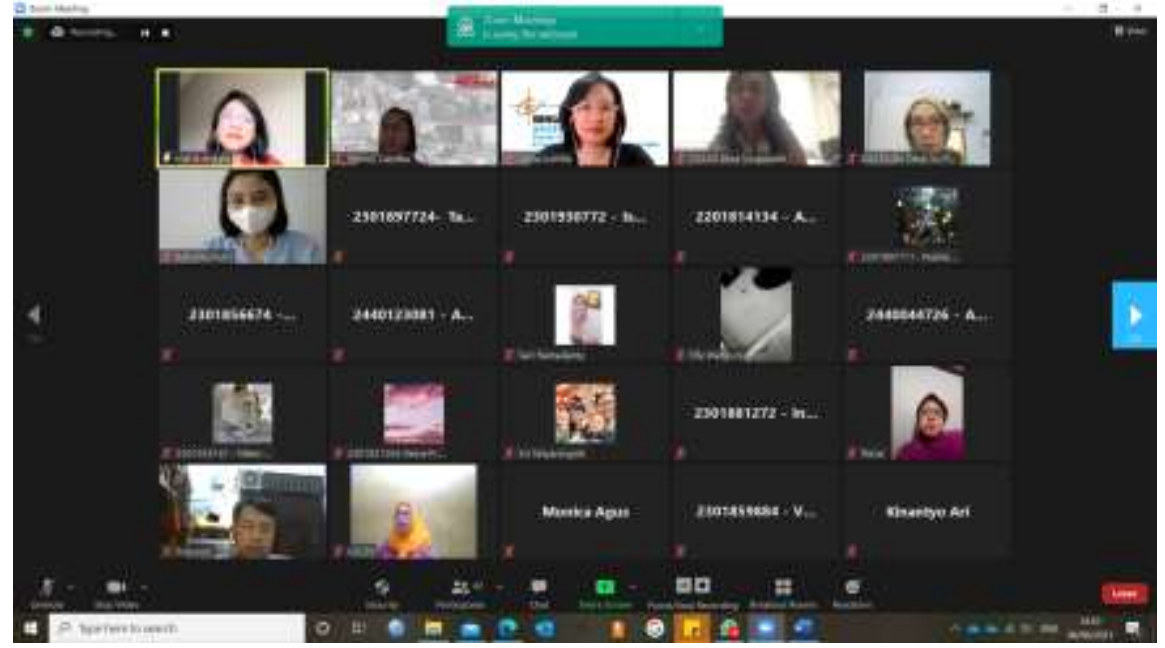

Gambar 1.

Pembukaan Kegiatan

Pelatihan oleh Head of

Communication

Department

Sumber: Dokumentasi Tim Pelaksana (2021)

Dalam sesi pemberian materi juga dibahas beberapa studi kasus untuk menambah wawasan para peserta. Setelah itu diadakan sesi tanya jawab dan diskusi untuk membahas masalahmasalah yang selama ini dihadapi oleh para pemilik UKM dalam melakukan branding melalui media sosial bagi produk mereka. Dengan metode tersebut diharapkan para peserta menjadi lebih paham. Para peserta pun cukup aktif bertanya dan mendiskusikan permasalahan mereka selama sesi tanya jawab dan diskusi berlangsung. Kemudian para peserta juga langsung mempraktekkan materi yang diajarkan di media sosial mereka.

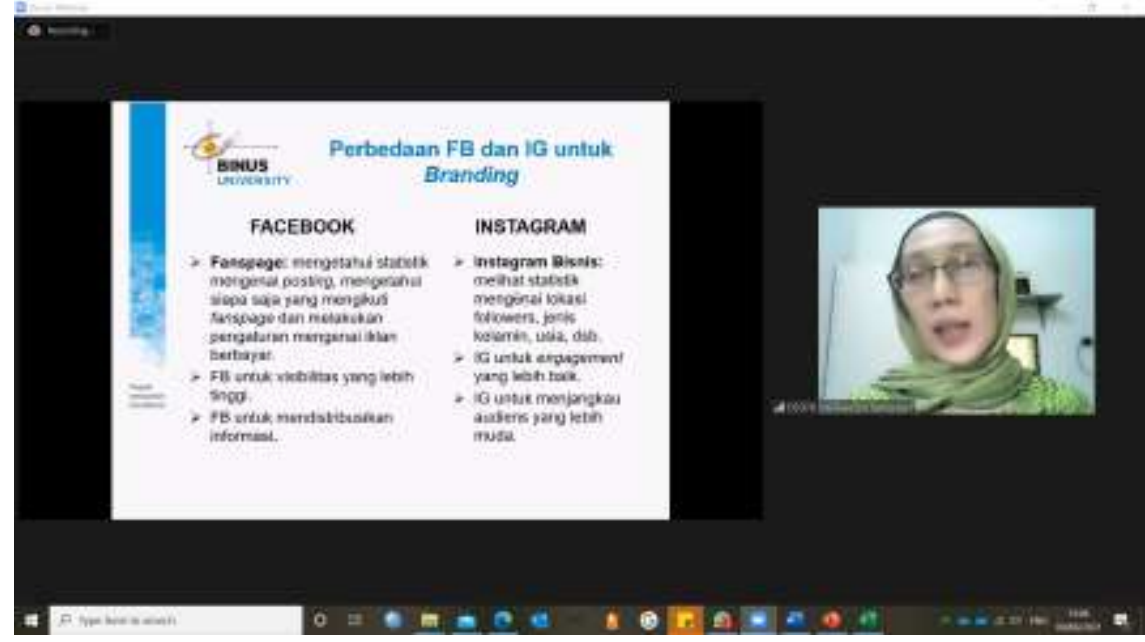

Gambar 2.

Penjelasan Materi dan

Studi Kasus oleh

Pemateri Minggu

Pertama Sesi Kedua

Sumber: Dokumentasi Tim Pelaksana (2021)

Sesi pelatihan kedua dilaksanakan pada hari Jum'at, 11 Juni 2021 pada pukul 14.00 hingga 16.00 WIB dengan topik Social Media Content Strategy for SMEs (Strategi Pembuatan Konten Media Sosial bagi UKM) dan terbagi menjadi dua sub topik: "Type of Content and Photo - Video Production for Social Media Branding" (Tipe Konten dan Foto - Produksi Video bagi Branding melalui Media Sosial) dengan pemateri Arleen Ariestyani, S.IKom., M.I.Kom. dan "Content Category and Writing The Story in SM Branding" (Kategori Konten dan Penulisan Kisah untuk Branding melalui Media Sosial) yang disampaikan oleh Yuanita Safitri, S.Sos., M.I.Kom.

Minggu ketiga pelatihan diadakan pada hari Jum'at, 18 Juni 2021 pada waktu yang sama, yakni 14.00 - 16.00 WIB dan topiknya adalah Social Media Tactic and Content Timeline for SMEs (Taktik Pemilihan Media Sosial dan Linimasa Konten bagi UKM). Terdapat dua sub topik 
dengan dua pemateri, yaitu "Tactics and Content Timeline in SM Branding" (Taktik dan Linimasa Konten untuk Branding melalui Media Sosial) yang disampaikan oleh Arsiyanti Lestari, S.Sos., M.I.Kom. dan "How to Increase Reach and Engagement in SM Branding" (Cara Meningkatkan Jangkauan dan Keterikatan dalam Branding melalui Media Sosial) dengan pemateri Dr. Siswantini, S.E., Ak., M.I.Kom.

Sesi terakhir atau minggu keempat pelatihan dilaksanakan pada hari Jum'at, 25 Juni 2021 juga di pukul 14.00 - 16.00 WIB dengan topik Social Media Evaluation and Measurement (Evaluasi dan Pengukuran Media Sosial). Sub topik pertama "The Measurement Tools of SM Branding" (Alat Pengukuran untuk Branding melalui Media Sosial) dibawakan oleh Mia Angeline, S.Kom., M.M., M.I.Kom. Sedangkan sub topik terakhir yang sekaligus menutup kegiatan pelatihan ini adalah "Budgeting in SM Branding" (Pembiayaan untuk Branding melalui Media Sosial) dengan pemateri Sari Ramadanty, S.Sos., M.Si.

Hasil dari pelaksanaan kegiatan pengabdian ini adalah sebagai berikut:

1. Para peserta pelatihan mulai mengenal dan mengetahui dasar-dasar bagi Social Media Branding untuk UKM, mengetahui strategi membuat konten yang baik di media sosial dan mempraktekkannya, memahami taktik pemilihan media sosial yang tepat bagi produk mereka serta mampu membuat jadwal pengunggahan konten yang efektif serta dapat melakukan evaluasi dan melakukan pengukuran keberhasilan strategi branding melalui media sosial yang mereka telah laksanakan.

2. Kegiatan pelatihan untuk pengabdian kepada masyarakat ini mendapatkan respon yang positif dari para pemilik UKM binaan Universitas Bina Nusantara Jakarta sehingga mereka berharap kegiatan pelaksanaan perngabdian kepada masyarakat ini dapat dilaksanakan lagi kedepannya dengan topik yang berbeda agar semakin menambah ilmu mereka dalam melakukan branding melalui media sosial bagi produk mereka .

Pelaksanaan kegiatan pengabdian masyarakat ini berjalan lancar serta hampir tanpa kendala yang berarti karena semua peserta mengikuti kegiatan dengan antusias dan aktif bertanya serta berdiskusi membicarakan berbagai permasalahan yang mereka hadapi dalam melakukan branding bagi produk mereka.

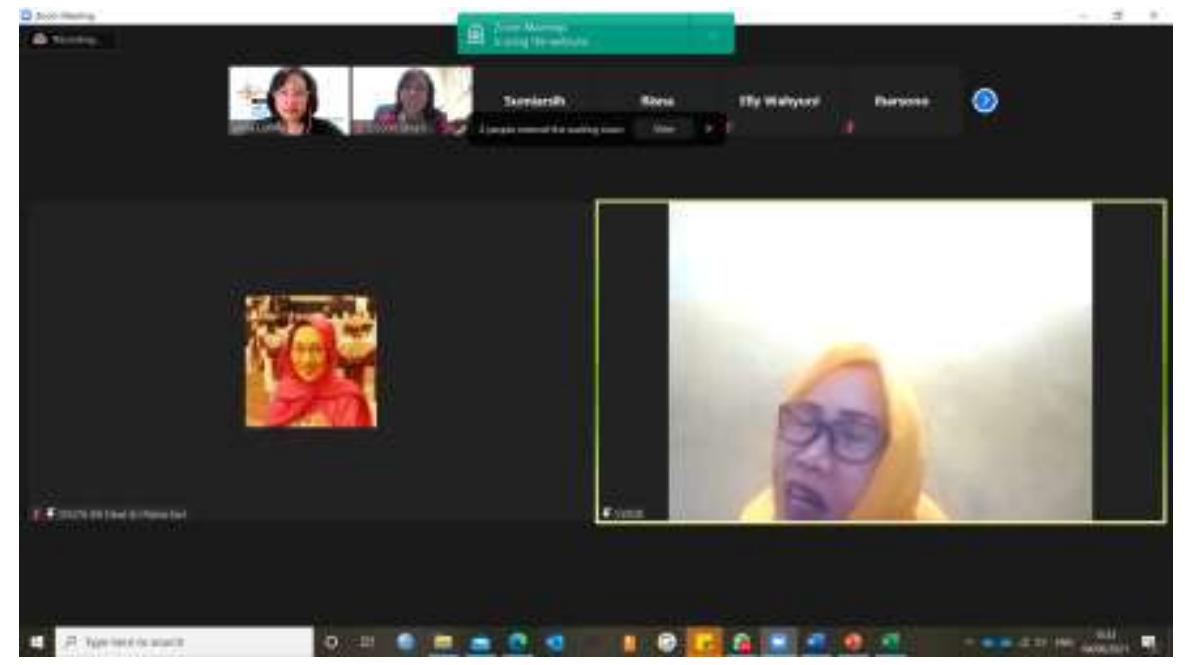

Gambar 3.

Sesi Tanya Jawab dan Diskusi dengan Para Peserta Pelatihan

Sumber: Dokumentasi Tim Pelaksana (2021) 


\section{Evaluasi Kegiatan}

Kegiatan pengabdian kepada masyarakat dalam bentuk pelatihan "Technology Use - Social media Branding for SMEs" ini telah berhasil memberi pembekalan pengetahuan dan pemahaman para peserta yang terdiri dari para pemilik UKM binaan Universitas Bina Nsantara Jakarta agar dapat melakukan branding melalui media sosial bagi produk-produk mereka.

Pihak mitra kerja mengharapkan kegiatan pengabdian kepada masyarakat ini dapat dilaksanakan kembali dengan topik pelatihan lain yang dapat berguna bagi kemajuan sektor UKM sebagai salah satu pilar perekonomian negara Indonesia.

\section{Kesimpulan}

\section{SIMPULAN}

Berdasarkan kegiatan pengabdian kepada masyarakat yang telah dilaksanakan, dapat disimpulkan bahwa pemahaman untuk melakukan branding bagi produk UKM melalui media sosial sangat diperlukan oleh para pemilik UKM agar dapat bersaing secara lebih baik di era globalisasi menghadapi merek-merek yang lebih mapan. Maka dari itu, pelatihan "Technology Use - Social Media Branding for SMEs" sangat membantu membekali mereka dengan pengetahuan dan pemahaman dalam melakukan branding melalui media sosial bagi produk mereka. Tujuan kegiatan ini sudah tercapai karena para peserta sudah mendapatkan bekal yang cukup untuk dapat melakukan branding melalui media sosial bagi produk UKM mereka.

\section{Saran kegiatan Lanjutan}

Terdapat permintaan dari mitra PkM ini untuk mengadakan pelatihan lanjutan dengan topik yang berbeda namun masih dalam lingkup ilmu komunikasi dan berguna bagi kemajuan sektor UKM, misalnya seperti pelatihan "Strategi Promosi Produk UKM melalui Website".

\section{REFERENSI}

BPS. (2020). Statistik E-Commerce 2020. www.bps.go.id. Diakses pada tanggal 22 Agustus 2021 dari

https:// www.bps.go.id/publication/2020/12/24/2548417ddc6dab8247553124/statis tik-e-commerce-2020.html.

Holt, D. (2016). Branding in the age of social media. Harvard Business Review, 41-51.

Rowles, D. (2018). Digital Branding A complete step-by-step guide to. London: Koganpage.

Sari, S. D. S. R., \& Haryanti, A. (2019). Upaya Marketing Public Relations PerusahaanPerusahaan E-Commerce Terbaik Di Indonesia Dalam Mempertahankan Brand Reputation Di Mata Konsumen. Jurnal Riset Manajemen dan Bisnis (JRMB) Fakultas Ekonomi UNIAT, 3(1), 457-468.

Setkab RI. (2020). PP Nomor 21 Tahun 2020. www.setkab.go.id. Diakses pada tanggal 8 Juni 2021 dari https://jdih.setkab.go.id/PUUdoc/176085/PP_Nomor_21_Tahun_2020.pdf. 


\section{About The Author}

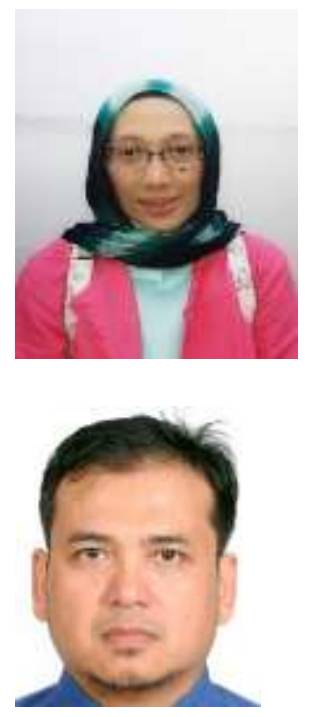

Siti Dewi Sri Ratna Sari, S.S., M.Si., kelahiran Surabaya, 12 Mei 1970. Penulis merupakan dosen Faculty Member Departemen Komunikasi di Fakultas Ekonomi dan Komunikasi Universitas Bina Nusantara Jakarta sejak tahun 2014. Sebelumnya, penulis mengembangkan karirnya sebagai dosen sejak tahun 2003 dengan pengalaman mengajar rumpun mata kuliah Public Relations di Universitas Mercu Buana, STIKOM InterStudi dan Universitas Muhammadiyah Jakarta. Email: siti.sari@binus.ac.id

Donant Alananto Iskandar, adalah dosen tetap program studi Manajemen, Institut Teknologi dan Bisnis Kalbis, Jakarta. Penulis merupakan dosen pengampu mata kuliah Metodologi Penelitian, Statistik Bisnis dan Ilmu Ekonomi. Sebelumnya, penulis juga bekerja sebagai praktisi di bidang jurnalistik dan pemasaran di beberapa media nasional dan perusahaan sampai akhirnya memilih berkarir sebagai dosen pada tahun 2006.

\section{Declarations}

\section{Funding}

Kegiatan ini merupakan bagian dari program Pengabdian kepada Masyarakat yang didukung oleh kerjasama antara Departemen Komunikasi dan Community Development Center Teach For Indonesia Universitas Bina Nusantara selama bulan Juni 2021.

\section{Competing Interests}

Tidak ada konflik kepentingan untuk diungkapkan. 